\title{
Synthesis and Biological Evaluation of Some New 1,2,3-Triazole Derivatives As Anti-microbial Agents
}

\author{
Bahaa G. M. Youssif ${ }^{1,2,{ }^{*}}$, Mostafa H. Abdelrahman ${ }^{3}$ \\ ${ }^{1}$ Department of Pharmaceutical Chemistry, Faculty of Pharmacy, Al-Jouf University, Al-Jouf-2014, Saudi \\ Arabia \\ ${ }^{2}$ Department of Pharmaceutical Organic Chemistry, Faculty of Pharmacy, Assiut University, Assiut- \\ 71526, Egypt \\ ${ }^{3}$ Department of Organic Chemistry, Faculty of Pharmacy, Al-Azhar University, Assiut Branch, Egypt \\ *Corresponding author: miar_ab_bahaa@yahoo.com
}

\section{ABSTRACT}

A series of 1,2,3-triazole derivatives bearing different chemical entities were prepared starting from 2-(4-phenyl$1 H$-1,2,3-triazol-1-yl)acetohydrazide, compound 2. The purity of all new compounds was checked by TLC and elucidation of their structures was confirmed by IR, ${ }^{1} \mathbf{H}$ and ${ }^{13} \mathbf{C}$ NMR along with High Resolution Mass Spectrometry (HRMS). All the target compounds were evaluated for their possible antimicrobial activity. Most of the tested compounds showed moderate to good antibacterial activity against most of the bacterial strains used in comparison with ciprofloxacin as a reference drug. The most active compounds were $\mathbf{4 a}, 9 \mathbf{a}, \mathbf{9 b}$, and 9 f. Results of antifungal activity revealed that most of the tested compounds showed a good antifungal activity in comparison to fluconazole as a reference drug. Compounds $\mathbf{4 a , 9 c , 9 d}$ and $9 f$ were the most active ones.

\section{Indexing terms/ Keywords}

1,2,3-Triazole; Synthesis; Antibacterial activity; Antifungal activity.

\section{Council for Innovative Research}

Peer Review Research Publishing System

Journal: Journal of Advances in Chemistry

Vol. 11, No. 2

editorjaconline@gmail.com

www.cirjac.com 


\section{1- INTRODUCTION}

1,2,3-Triazoles are an important class of heterocycles due to their wide range of applications as synthetic intermediates and pharmaceuticals [1-2]. Several therapeutically interesting 1,2,3-triazoles have been reported, including anti-HIV agents [3-6], antimicrobial compounds [7], ß3-selective adrenergic receptor agonists [8], kinase inhibitors [9-10] and other enzyme inhibitors [11-12]. The 1,2,3-triazole moiety is also present in a number of drugs, for example, the B-lactam antibiotic tazobactam [13] and the cephalosporin cefatrizine [14].

Morbidity and mortality due to enteric bacterial infections have caused important health problems worldwide, mainly in the developing countries [15-16]. Toxicity and resistance to the drugs also have played an important role in treatment failure [17]. Consequently, there is an urgent need to screen new compounds for the development of new antibacterial agents.

We report simple and efficient methods for preparation of 1,2,3-triazole derivatives bearing different chemical entities that promise superior antimicrobial activity.

\section{2- RESULTS AND DISCUSSION}

\subsection{Chemistry}

The key intermediate ethyl 2-(4-phenyl-1H-1,2,3-triazol-1-yl)acetate, compound 1 was prepared according to a reported procedure and its structure was confirmed by matching its physical and spectral data with the reported one[18].

The novel 2-(4-phenyl-1H-1,2,3-triazol-1-yl)acetohydrazide, compound 2 was obtained through condensation of compound 1 with hydrazine hydrate by heating the reactants in ethanol at reflux for $6 \mathrm{~h}$, Scheme 1. IR spectrum of compound 2 showed two bands at 3290 and $3160 \mathrm{~cm}^{-1}$ due to $\mathrm{NH}$ and $\mathrm{NH}_{2}$ functions, in addition to a band at 1658 corresponding to carbonyl group. ${ }^{1} \mathbf{H}$ NMR spectrum of compound $\mathbf{2}$ showed signals derived from hydrazide structure appeared at $4.42 \mathrm{ppm}\left(-\mathrm{NHNH}_{2}\right)$ and $9.57\left(-\mathrm{NHNH}_{2}\right) \mathrm{ppm}$ integrating for two and one protons, respectively (exchangeable with $\mathrm{D}_{2} \mathrm{O}$ ). In addition, the spectrum also showed singlet signal at $5.10 \mathrm{ppm}$ for $\left(\mathrm{NCH}_{2}\right)$. HRMS of compound 2: Found 218.1033, Calculated for $\left(\mathbf{C}_{10} \mathbf{H}_{12} \mathbf{N}_{5} \mathbf{O}^{+}\right) 218.1036$.

Hydrazide 2 was allowed to react with phthalic anhydride in glacial acetic acid by heating the reactants at reflux for $2 \mathrm{~h}$ to afford the new phthalimide derivative $\mathbf{3}$ in a $78 \%$ yield, Scheme 1. IR spectrum of compound $\mathbf{3}$ showed one band at $3260 \mathrm{~cm}^{-1}$ due to $(-\mathrm{NH})$ stretching and two bands at 1699 and 1648 for carbonyl groups. ${ }^{1} \mathrm{H}$ NMR spectrum of compound 3 displayed no signals belonging to $-\mathrm{NH}_{2}$ group. HRMS of compound 3: Found 348.1087, Calculated for $\left(\mathrm{C}_{18} \mathrm{H}_{14} \mathrm{~N}_{5} \mathrm{O}_{3}{ }^{+}\right) 348.1091$

The novel thiosemicarbazide derivatives 4a-c were obtained in $76-84 \%$ yields through the reaction of acid hydrazide 2 with the appropriate isothiocyanate by heating the reactants at reflux in ethanol for $2 \mathrm{~h}$. Furthermore, the thiosemicarbazides $4 \mathrm{a}-\mathrm{c}$ were cyclized in hot $\mathrm{NaOH}$ solution as a base catalyzed reaction to obtain the novel 5mercapto-4-substituted-4H-1,2,4-triazole derivatives 5a-c.

The IR spectra of compounds 4a-c showed strong absorption bands at $3265-3234 \mathrm{~cm}^{-1}$ and $1666-1652 \mathrm{~cm}^{-1}$ for the $\mathrm{NH}$ and $\mathrm{C}=\mathrm{O}$ groups, respectively. In addition to a strong absorption band at $1190 \mathrm{~cm}-1$ due to $(\mathrm{C}=\mathrm{S})$ group. Meanwhile IR spectra of compounds 5a-c displayed no bands belonging to $\mathrm{NH}$ and $\mathrm{C}=\mathrm{O}$ groups; instead a new bands at 2988-2962 $\mathrm{cm}^{-1}$ for SH group. 


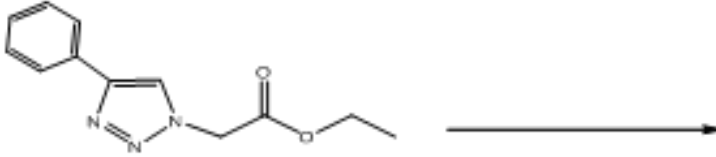

(1)

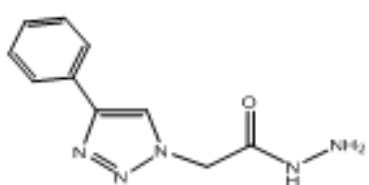

(2)

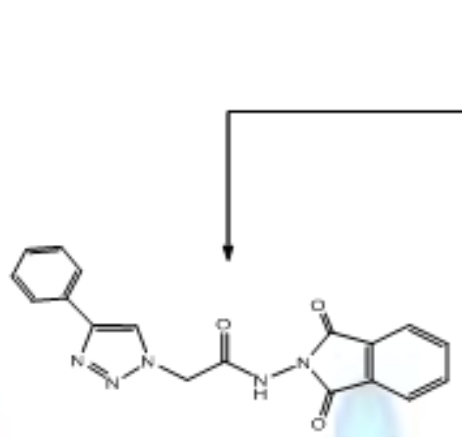

(3)

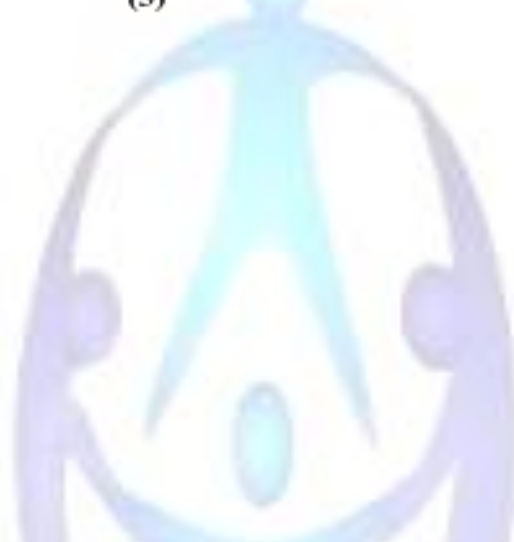

Scheme 1 Synthesis of compounds 2, 3, 4a-c, and 5a-c

Moreover, the novel oxadiazole 6 was synthesized in 87\% yield through cyclization of the acid hydrazide 2 using potassium hydroxide and carbon disulfide in hot ethanolic solution. IR spectrum of compound 6 showed a band at 2961 $\mathrm{cm}^{-1}$ due to SH group. HRMS of compound 6: Found 260.0594, Calculated for $\left(\mathbf{C}_{11} \mathbf{H}_{10} \mathbf{N}_{5} \mathbf{O S}^{+}\right) 260.0601$.

The intermediate potassium 2-(2-(4-phenyl-1H-1,2,3-triazol-1-yl)acetyl)hydrazine carbodithioate 7 was prepared from hydrazide 2 and carbon disulfide in ethanolic potassium hydroxide solution with the aim to be cyclized to the novel triazole $\mathbf{8}$ under the effect of hydrazine hydrate. Structure of compound $\mathbf{8}$ was elucidated by spectral methods of analyses. IR spectrum of compound 8 showed two bands at 3270 and $3135 \mathrm{~cm}^{-1}$ due to (NH) stretching, a band at $2720 \mathrm{~cm}^{-1}$ for SH group and a strong band at $1299 \mathrm{~cm}^{-1}(\mathrm{C}=\mathrm{S})$ stretching (thiol-thionetautomers). IR spectrum of compound 8 was devoid of absorption bands around $1660 \mathrm{~cm}^{-1}$ due to carbonyl group of hydrazide. ${ }^{1} \mathrm{H}$ NMR spectrum of compound 8 displayed no signalsbelonging to $-\mathrm{NH}_{2}$ and $-\mathrm{CONH}$ groups; instead, a new singlet signal appeared at 5.68 ppm (exchangeable with $\mathrm{D}_{2} \mathrm{O}$ ) due to $-\mathrm{NH}_{2}$ of triazole ring equivalent to two protons and a broad signal at $13.85 \mathrm{ppm}$ due to exchanged $-\mathrm{NH}$ proton of triazole ring. HRMS of compound 8: Found 274.0867, Calculated for $\left(\mathbf{C}_{11} \mathbf{H}_{12} \mathbf{N}_{7} \mathbf{S}^{+}\right) 274.0869$.

The target compounds; 9a-f were synthesized by condensation of compound 2 with (un)substituted benzaldehydes or acetophenone Scheme 2. The structures of compounds 9a-f were confirmed by spectral methods of analyses. The IR spectra of compounds 9a-f showed strong absorption bands at $3255-3160 \mathrm{~cm}^{-1}$ and $1680-1668 \mathrm{~cm}^{-1}$ for the $\mathrm{NH}$ and $\mathrm{C}=\mathrm{O}$ groups, respectively. 

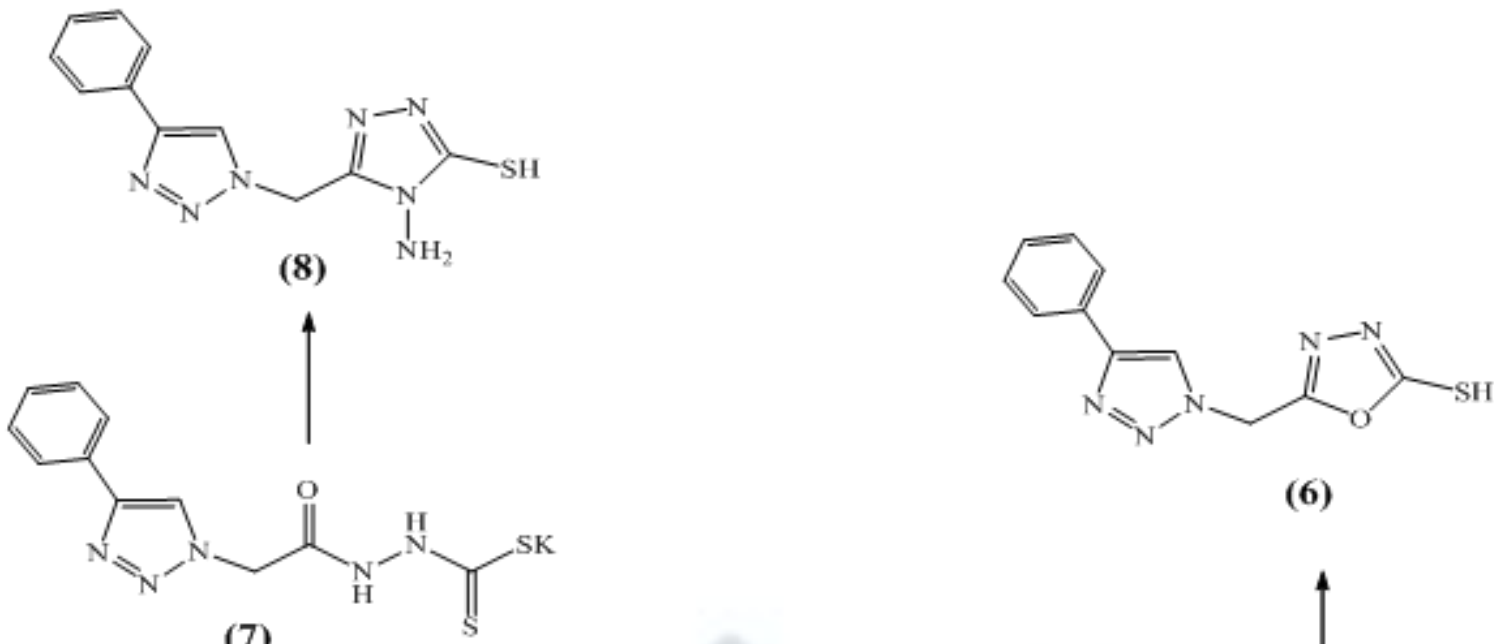

(6)

(7)

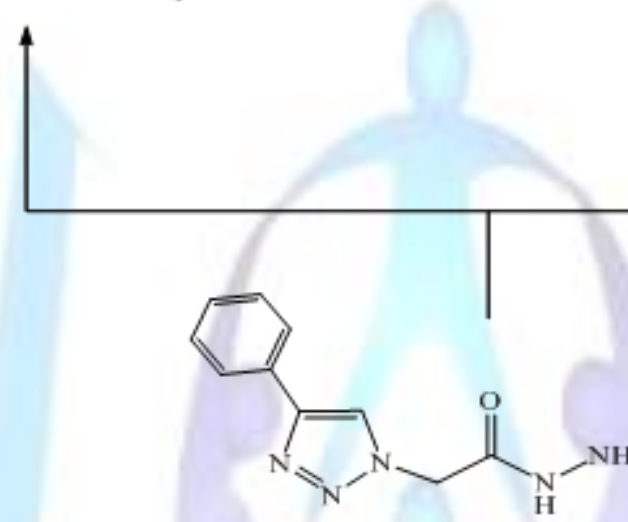

(2)
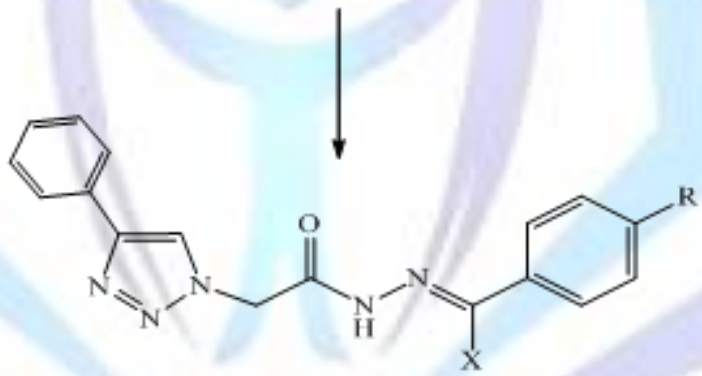

(9a-f)

$\mathbf{X}=\mathbf{H}$

$\mathbf{R}=\mathbf{H}, \mathbf{C l}, \mathbf{B r}, \mathbf{F}, \mathbf{N}\left(\mathrm{CH}_{3}\right)_{2}$

$\mathrm{X}=\mathrm{CH}_{3}$

$\mathbf{R}=\mathbf{H}$

Scheme 2 Synthesis of compounds 6-8 and 9a-f 
Table 1. Structures and yields of compounds 2, 3, 4a-c, 5a-c, 6, 8, and 9a-f

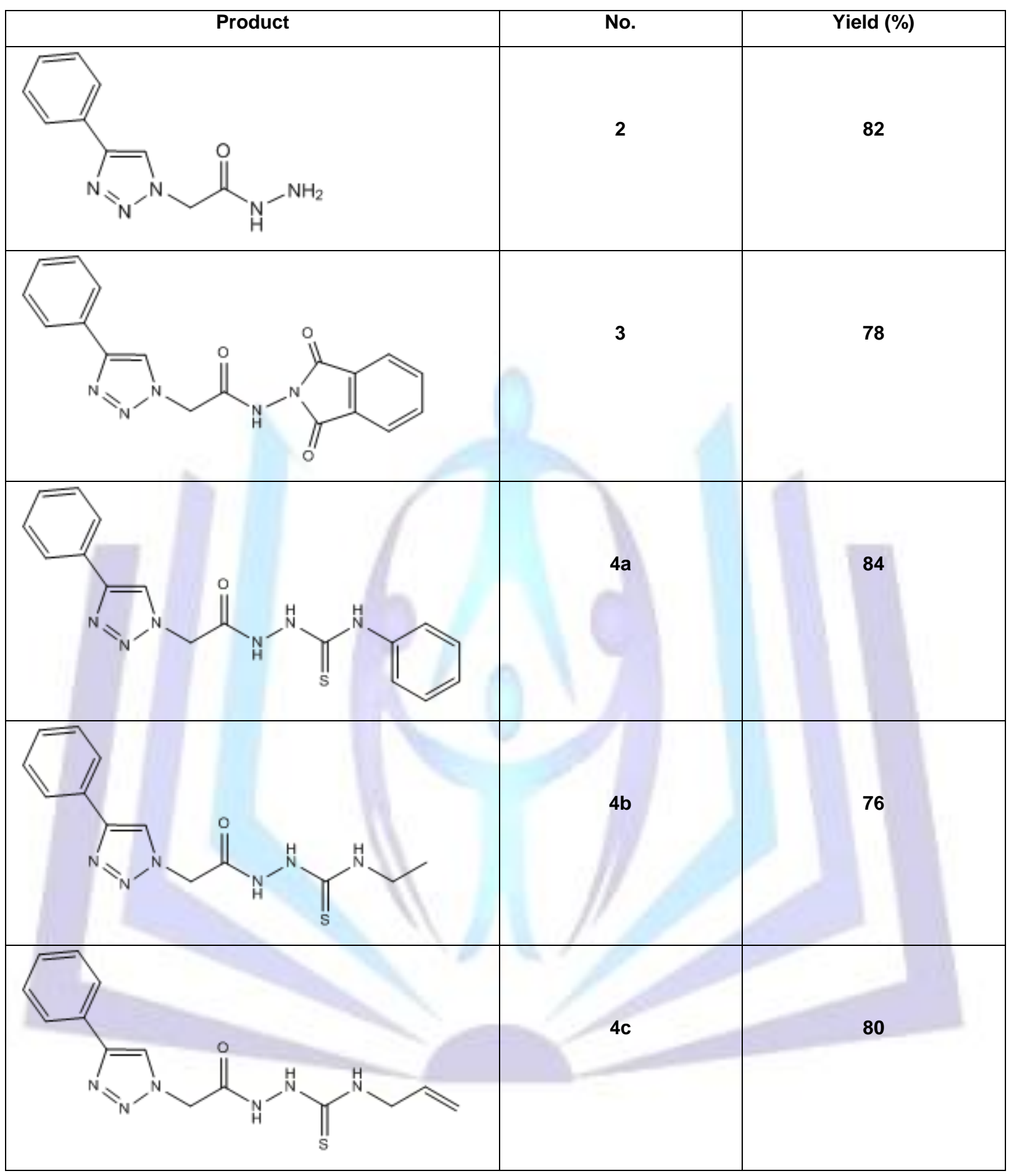




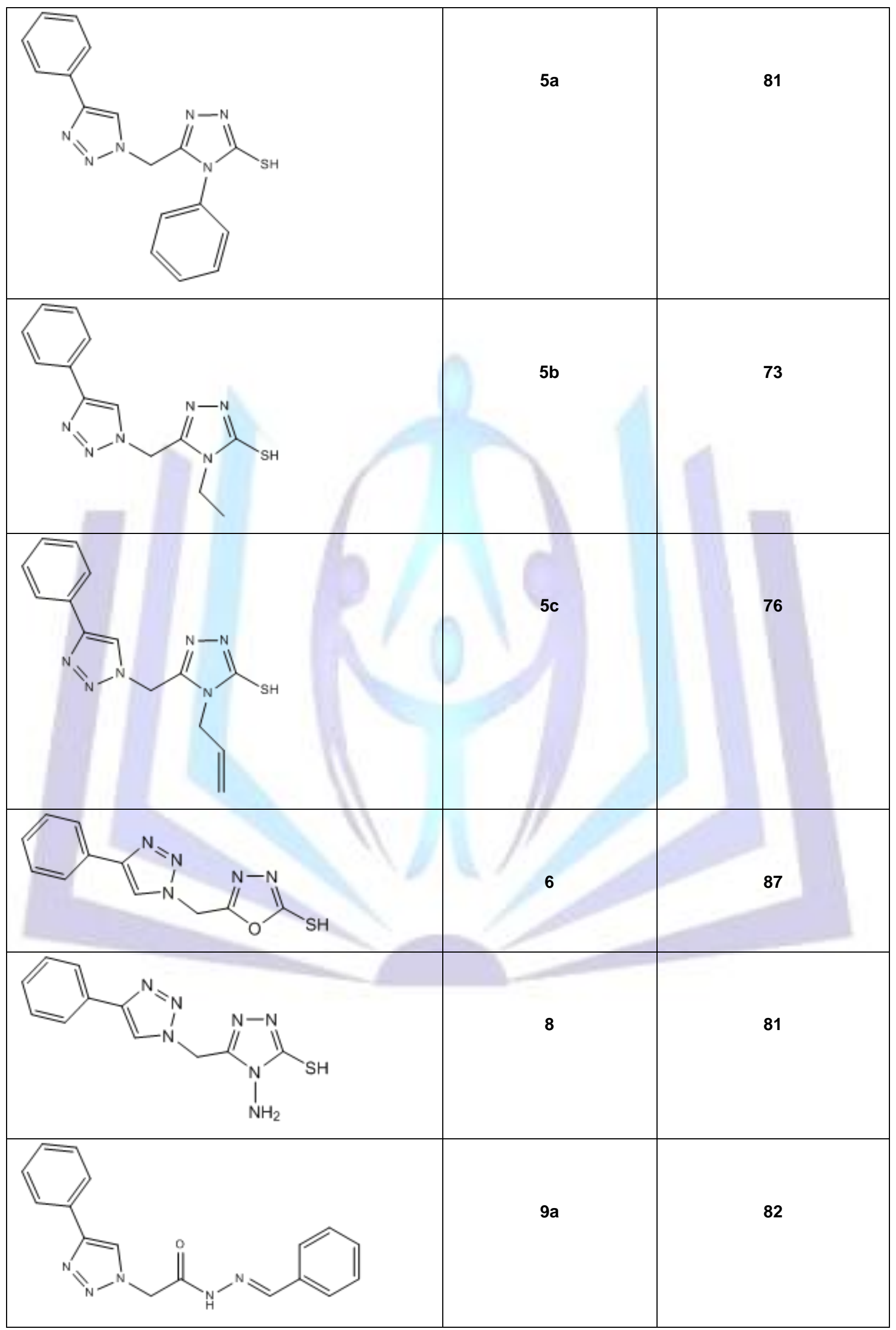




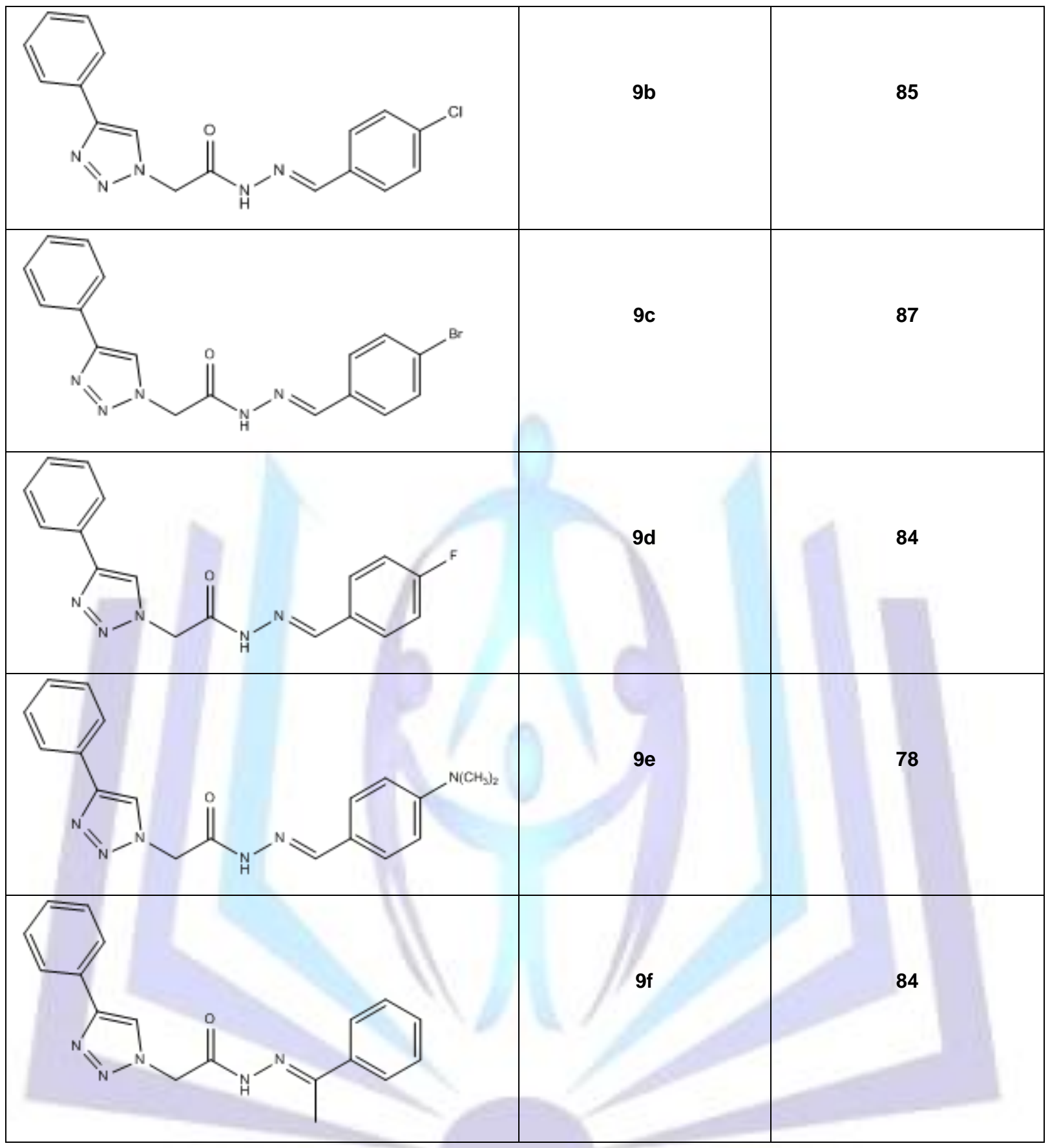

\subsection{Biology}

The results of the preliminary testing of the antibacterial activity of the final compounds are given in Table II. The synthesized compounds 2, 3, 4a-c, 5a-c, 6, 8, and 9a-f were tested for their in vitro antibacterial activity against Staphylococcus aureusas a representative of Gram positive strains and Escherichia coli as a Gram negative strain using ciprofloxacin as a reference drug. The result revealed that most of the newly synthesized compounds exhibited promising antibacterial activity comparable to ciprofloxacin against the test organisms (Table II).

The hydrazide derivative compound 2, was found to exhibit antibacterial activity nearly $48 \%$ that of ciprofloxacin against Staphylococcus aureus, however it showed only $40 \%$ activity of ciprofloxacin against E.Coli.

According to the results in Table II, it can be noticed that conversion of hydrazide derivative, compound 2 into compound $\mathbf{3}$ decreased the activity against Staphylococcus aureus as it showed only $38 \%$ activity of ciprofloxacin.

Compounds 4a-c were found to exhibit pronounced antibacterial activity which ranged from $60-73 \%$ that of standard drug against Staphylococcus aureus and $45-60 \%$ that of ciprofloxacin against E.Coli. It is worthy-mentioning that compound $4 \mathrm{a}$ showed the highest activity (73\%) against Staphylococcus aureus and $60 \%$ activity of ciprofloxacin against E.Coli. 
Furthermore, compounds 5a-c exhibited moderate activity against Staphylococcus aureusand their activity was $53-60 \%$ that of ciprofloxacin, but they showed weak activity (45-47\% that of ciprofloxacin) against E.Coli and that compound 5a was the most active compound against Staphylococcus aureusas it showed $60 \%$ that of ciprofloxacin while it showed only $47 \%$ activity against E.Coli. It was noticed that cyclization of thiosemicarbazides $4 a-c$ to their corresponding triazole derivatives 5 a-c led to decrease of the antibacterial activity.

The oxadiazole derivative, compound 6 showed moderate activity against Staphylococcus aureusand its activity was $68 \%$ that of ciprofloxacin while it showed only $55 \%$ activity of ciprofloxacin against E.Coli. Meanwhile, the conversion of hydrazide 2 into the amino triazole derivative, compound $\mathbf{8}$ did not show a significant improvement in the antibacterial characters of compound 2 .

Compounds 9a-f were found to exhibit pronounced antibacterial activity which ranged from $65-85 \%$ that of standard drug against Staphylococcus aureus and $50-80 \%$ that of ciprofloxacin against E.Coli. It is worthy-mentioning that compound 9 f showed the highestactivity (85\%) against Staphylococcus aureus while compound $9 \mathbf{d}$ was the most active derivative against E.Coli(80\% avtivity).

Table II. Inhibitory zone diameter (mm) of compounds 2, 3, 4a-c, 5a-c, 6, 8, and 9a-f

\begin{tabular}{|c|c|c|c|}
\hline Compd. No. & $\begin{array}{c}\text { Gram-positive bacteria } \\
\text { Staph. aureus }\end{array}$ & $\begin{array}{c}\text { Gram-negative bacteria } \\
\text { E. coli }\end{array}$ & $\begin{array}{l}\text { Fungi } \\
\text { C. Albicans }\end{array}$ \\
\hline 2 & 19 & 16 & 16 \\
\hline 3 & 15 & 16 & 16 \\
\hline $4 a$ & 29 & 24 & 28 \\
\hline $4 b$ & 25 & 21 & 25 \\
\hline $4 c$ & 24 & 18 & 26 \\
\hline $5 a$ & 24 & 19 & 21 \\
\hline $5 b$ & 20 & 18 & 22 \\
\hline $5 c$ & 21 & 18 & 20 \\
\hline 6 & 27 & 22 & 24 \\
\hline 8 & 20 & 21 & 18 \\
\hline $9 a$ & 28 & 20 & 26 \\
\hline $9 b$ & 28 & 24 & 24 \\
\hline $9 c$ & 26 & 20 & 30 \\
\hline $9 d$ & 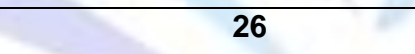 & 32 & 30 \\
\hline $9 e$ & 26 & 24 & 32 \\
\hline $9 f$ & 34 & 26 & 30 \\
\hline Ciprofloxacin & 40 & +2 & -- \\
\hline Fluconazole & -- & -- & 40 \\
\hline
\end{tabular}

All the synthesized compounds 2, 3, 4a-c, 5a-c, 6, 8, and 9a-f were tested as potential antifungal agents against Candida albicans using Fluconazole as a reference drug (Table II).

The results revealed that the tested compounds showed a varying degree of antifungal activity against the test organism Compound 2 showed activity 40\% that of fluconazole. Moreover, further derivatization of compound 2 with different (un)substituted benzaldehydes and acetophenone, compounds 9a-f affords compounds with improved antifungal activity against Candida albicans, showing activity $50-80 \%$ that of fluconazole. Compound $9 \mathrm{e}$ displayed the higher antifungal activity among the other derivatives as it showed $80 \%$ activity of fluconazole. 


\section{CONCLUSION}

In conclusion, several 1,2,3-triazole derivatives bearing different chemical entities were synthesized. A microbiological study was undertaken to evaluate the effect of the synthesized compounds on different bacterial and fungal strains. The results of the preliminary testing of the antibacterial activity of the final compounds revealed that the majority of the synthesized compounds show varying degrees of inhibition against the tested microorganisms. In general, the inhibitory activity against the Gram-positive bacteria was higher than against the Gram-negative bacteria. The triazole derivatives $\mathbf{4 a}, 9 \mathbf{a}, \mathbf{9 b}$, and $\mathbf{9 f}$, displayed the highest activity. Results of antifungal activity revealed that all compounds showed a weak to a good antifungal activity and that compounds $9 \mathrm{c}, 9 \mathrm{~d}, 9 \mathrm{e}$ and $9 \mathrm{f}$ were the most active ones.

\section{EXPERIMENTAL}

\subsection{Chemistry}

Reagents used for synthesis were purchased from Sigma-Aldrich (Gillingham - Dorest, UK) and MERCK (Schuchardt, Germany). All solvents were obtained from commercial suppliers and used without further purification. The starting material ethyl 2-(4-phenyl-1 H-1,2,3-triazol-1-yl)acetate, compound 1[18] was prepared according to reportedprocedure.

Melting points were determined on an electro thermal melting point apparatus [Stuart Scientific, model SMP3, England, $\mathrm{UK}$ ], and were uncorrected. Pre-coated silica gel plates (kieselgel $0.25 \mathrm{~mm}, 60 \mathrm{G}$ F254, Merck, Germany) were used for TLC monitoring of reactions. The developing solvent systems of $\mathrm{CHCl}_{3} / \mathrm{CH}_{3} \mathrm{OH}(9.5: 0.5 \mathrm{~V} / \mathrm{V}$ ) were used and the spots were detected at $254 \mathrm{~nm}$ wavelength using ultraviolet lamp (Spectroline, model CM-10, USA). The target compounds were crystallized from ethanol unless otherwise specified. IR spectra ( $\mathrm{KBr}$ discs) were recorded on a shimadzu IR-470 spectrometer (Shimadzu, Kyoto, Japan) at Faculty of Pharmacy, Assiut University, Assiut. NMR Spectra were taken using a Varian Unity INOVA $400 \mathrm{MHz}$ and Bruker AC250 MHz spectrometers for proton and carbon. All numbers referring to NMR data obtainedare in parts per million $(\mathrm{ppm})$ relative to TMS as an internal standard, using DMSO-d $\mathrm{d}_{6}$, unless otherwise specified, as a solvent, and deuterium oxide was used for the detection of exchangeable protons.. High resolution mass spectrometric data were obtained using the EPSRC mass spectrometry centre in Swansea and Thermo Instruments MS system (LTQ XL/LTQ Orbitrap Discovery) coupled to a Thermo Instruments HPLC system (Accela PDA detector, Accela PDA autosampler and Pump) at university of Aberdeen.

\section{Synthesis of 2-(4-phenyl-1H-1,2,3-triazol-1-yl)acetohydrazide (2)}

To a solution of ethyl 2-(4-phenyl-1H-1,2,3-triazol-1-yl)acetate, compound 1 (3.17 g, $0.013 \mathrm{~mol})$ in absolute ethanol $(40 \mathrm{~mL})$, hydrazine hydrate $99 \%(1.00 \mathrm{~g}, 0.02$ mole) was added. The reaction mixture was refluxed for $6 \mathrm{~h}$, and then cooled. The precipitated product was filtered, washed with cold ethanol, dried, and crystallized from ethanol as white crystals.

\section{Synthesis of N-(1,3-dioxoisoindolin-2-yl)-2-(4-phenyl-1H-1,2,3-triazol-1-yl)acetamide (3)}

A mixture of the hydrazide $1(0.001 \mathrm{~mol})$ and phthalic anhydride $(0.001 \mathrm{~mol})$ in glacial acetic acid $(10 \mathrm{~mL})$ was heated at reflux for $2 \mathrm{~h}$, after cooling, the separated product was filtered and crystallized from $\mathrm{DMF} / \mathrm{H}_{2} \mathrm{O}$.

\section{General procedure for preparation of N-alkyl/aryl-2-(2-(4-phenyl-1H-1,2,3-triazol-1- yl)acetyl)hydrazine carbothioamide (4a-c)}

A mixture of the hydrazide $2(0.002 \mathrm{~mol})$ and the appropriate isothiocyanate $(0.002 \mathrm{~mol})$ in ethanol $(10 \mathrm{~mL})$ was heated at reflux for $2 \mathrm{~h}$, after cooling, the separated product was filtered and crystallized from ethanol.

\section{General procedure for preparation of 4-alkyl/aryl-5-((2-(4-phenyl-1H-1,2,3-triazol-1-yl)methyl)- 4H-1,2,4-triazole-3-thiol (5a-c)}

Compounds 4a-c $(0.002 \mathrm{~mol})$ were dissolved in $\mathrm{NaOH}(2 \mathrm{~N}, 10 \mathrm{~mL})$, then heated under reflux for $2 \mathrm{~h}$. The solution was cooled, filtered and then acidified with $\mathrm{HCl}(2 \mathrm{~N})$. The separated solid was filtered and crystallized from $\mathrm{DMF} / \mathrm{H}_{2} \mathrm{O}$.

\section{Synthesis of 5-((4-phenyl-1H-1,2,3-triazol-1-yl)methyl)-1,3,4-oxadiazole-2-thiol (6)}

The acid hydrazide $2(0.002 \mathrm{~mol})$ was stirred in ethanol $(20 \mathrm{~mL})$ containing potassium hydroxide $(0.002 \mathrm{~mol})$ for 1 $\mathrm{h}$ until a clear solution was obtained. Carbon disulfide $(0.005 \mathrm{~mol})$ was added dropwise to the stirred reaction mixture, and then it was heated under reflux for $6 \mathrm{~h}$. The reaction mixture was concentrated, cooled, and acidified with diluted $\mathrm{HCl}$. The separated product was filtered, washed with water, and crystallized from ethanol.

\section{Synthesis of potassium 2-(2-(4-phenyl-1H-1,2,3-triazol-1-yl)acetyl)hydrazinecarbodithioate (7)}

Carbon disulfide $(0.015 \mathrm{~mol})$ was added dropwise to an ice-cooled solution of ethanol $(20 \mathrm{~mL})$ containing $\mathrm{KOH}$ $(0.01 \mathrm{~mol})$ and hydrazide $2(0.01 \mathrm{~mol})$. The mixture was stirred for $14 \mathrm{~h}$, and then dry diethyl ether $(10 \mathrm{~mL}) \mathrm{was}$ added. The separated solid was filtered and then washed twice with diethyl ether $(20 \mathrm{~mL})$. The obtained product was used in the next reaction without further purification. 


\section{Synthesis of 4-amino-5-((4-phenyl-1H-1,2,3-triazol-1-yl)methyl)-4H-1,2,4-triazole-3-thiol (8)}

A mixture of intermediate $7(0.005 \mathrm{~mol})$ and hydrazine hydrate $(99 \% ; 0.01 \mathrm{~mol})$ in ethanol $(20 \mathrm{~mL})$ was refluxed for $4 \mathrm{~h}$. the reaction mixture was diluted with cold water, then neutralized by portion wise addition of concentrated $\mathrm{HCl}$. The formed precipitate was filtered, washed with water, and crystallized from ethanol.

\section{General procedure for preparation of N-arylidene-2-(4-phenyl-1H-1,2,3-triazol-1-yl)aceto- hydrazide (9a-f)}

To a suspension of hydrazide $2(0.002 \mathrm{~mol})$ in ethanol $(10 \mathrm{~mL})$ and the appropriate aryl aldehyde $(0.002 \mathrm{~mol}), 2$ drops of glacial acetic acid were added, and then the reaction mixture was heated under reflux for 4-6 h. The reaction mixture was cooled and the precipitated product was filtered, washed with cold ether and crystallized from ethanol.

\section{Spectral Data of New Compounds}

2-(4-phenyl-1H-1,2,3-triazol-1-yl)acetohydrazide(2). Yield (82\%), mp 186-188 ${ }^{\circ} \mathrm{C} ; \mathrm{IR}$ spectrum $\left(\mathrm{v} / \mathrm{cm}^{-1}\right): 3290$, $3160(\mathrm{NH}) ; 1658(\mathrm{C}=\mathrm{O}) ; 1620,1584,1530,1485,1460(\mathrm{C}=\mathrm{N} / \mathrm{C}=\mathrm{C}) ;{ }^{1} \mathrm{H}$ NMR spectrum (DMSO-d6): $\delta(\mathrm{ppm}): 9.57(\mathrm{~s}$, $1 \mathrm{H}) ; 8.54(\mathrm{~s}, 1 \mathrm{H}) ; 7.91-7.84(\mathrm{~m}, 2 \mathrm{H}) ; 7.45(\mathrm{t}, \mathrm{J}=7.6 \mathrm{~Hz}, 2 \mathrm{H}) ; 738-7.28(\mathrm{~m}, 1 \mathrm{H}) ; 5.10(\mathrm{~s}, 2 \mathrm{H}) ; 4.42(\mathrm{~s}, 2 \mathrm{H}) ;{ }^{13} \mathrm{C} \mathrm{NMR}$ spectrum (DMSO-d6): $\delta$ (ppm): 164.79; 146.21; 130.72; 128.94; 127.88; 125.17; 122.82; 50.70; HRMS calcd for $\mathrm{C}_{10} \mathrm{H}_{11} \mathrm{~N}_{5} \mathrm{O}[\mathrm{M}+\mathrm{H}]^{+}$218.1036 Found 218.1033.

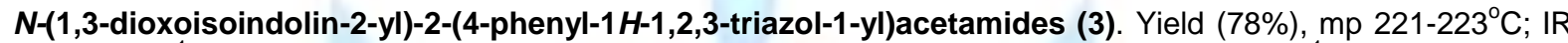
spectrum $\left(\mathrm{v} / \mathrm{cm}^{-1}\right): 3260(\mathrm{NH}) ; 1699 ; 1648(\mathrm{C}=\mathrm{O}) ; 1610 ; 1594 ; 1520 ; 1487 ; 1460(\mathrm{C}=\mathrm{N} / \mathrm{C}=\mathrm{C}) ;{ }^{1} \mathrm{H}$ NMR spectrum (DMSO-d6): $\delta$ (ppm): 8.62 (d, J = 1.0 Hz, 1H); 8.01-7.83 (m, 6H); 7.45 (t, J = 7.7 Hz, 2H); $7.34(\mathrm{td}, \mathrm{J}=7.2 \mathrm{~Hz}, 1.3 \mathrm{~Hz}$, $1 \mathrm{H}) ; 5.56(\mathrm{~s}, 2 \mathrm{H}) ;{ }^{13} \mathrm{C}$ NMR spectrum (DMSO-d6): $\delta$ (ppm): 165.33; 164.76; 146.32; 135.33; 130.55; 129.40; 128.94; $127.94 ; 125.18 ; 123.83 ; 123.11 ; 50.09$; $\mathrm{HRMS}$ calcd for $\mathrm{C}_{18} \mathrm{H}_{13} \mathrm{~N}_{5} \mathrm{O}_{3}[\mathrm{M}+\mathrm{H}]^{+} 348.1091$ Found 348.1087 .

N-phenyl-2-(2-(4-phenyl-1 H-1,2,3-triazol-1-yl)acetyl)hydrazinecarbothioamide (4a). Yield (84\%), mp 198-200 ${ }^{\circ} \mathrm{C}$; IR spectrum $\left(\mathrm{v} / \mathrm{cm}^{-1}\right)$ : $3265(\mathrm{NH}) ; 1658(\mathrm{C}=\mathrm{O}) ; 1610 ; 1590 ; 1527 ; 1482 ; 1460(\mathrm{C}=\mathrm{N} / \mathrm{C}=\mathrm{C}) ; 1191(\mathrm{C}=\mathrm{S}) ;{ }^{1} \mathrm{H} \mathrm{NMR}$ spectrum (DMSO-d6): $\delta(\mathrm{ppm}): 10.56(\mathrm{~s}, 1 \mathrm{H}) ; 9.79(\mathrm{~d}, \mathrm{~J}=9.6 \mathrm{~Hz}, 2 \mathrm{H}) ; 8.56(\mathrm{~s}, 1 \mathrm{H}) ; 7.88(\mathrm{~d}, \mathrm{~J}=7.6 \mathrm{~Hz}, 2 \mathrm{H}) ; 7.50$ $7.30(\mathrm{~m}, 7 \mathrm{H}) ; 7.20$ (t, J = $7.3 \mathrm{~Hz}, 1 \mathrm{H}) ; 5.29$ (s, 2H); ${ }^{13} \mathrm{C}$ NMR spectrum (DMSO-d6): $\delta$ (ppm): 146.25; 138.97; 130.65; 128.95; 128.19; $127.91 ; 125.17 ; 122.97 ; 50.68$; HRMS calcd for $\mathrm{C}_{17} \mathrm{H}_{16} \mathrm{~N}_{6} \mathrm{O}_{5}[\mathrm{M}+\mathrm{H}]^{+} 353.1179$ Found 353.1178.

N-ethyl-2-(2-(4-phenyl-1H-1,2,3-triazol-1-yl)acetyl)hydrazinecarbothioamide(4b). Yield (76\%), mp $224-226$ ${ }^{\circ} \mathrm{C}$; IR spectrum $\left(\mathrm{v} / \mathrm{cm}^{-1}\right)$ : $3245(\mathrm{NH}) ; 1666(\mathrm{C}=\mathrm{O}) ; 1610 ; 1590 ; 1527 ; 1482 ; 1460(\mathrm{C}=\mathrm{N} / \mathrm{C}=\mathrm{C}) ; 1192(\mathrm{C}=\mathrm{S}) ;{ }^{1} \mathrm{H} \mathrm{NMR}$ spectrum (DMSO-d6): $\delta(\mathrm{ppm}): 10.31(\mathrm{~s}, 1 \mathrm{H}) ; 9.34(\mathrm{~s}, 1 \mathrm{H}) ; 8.54(\mathrm{~s}, 1 \mathrm{H}) ; 8.16(\mathrm{t}, \mathrm{J}=5.6 \mathrm{~Hz}, 1 \mathrm{H}) ; 7.87(\mathrm{~d}, \mathrm{~J}=7.6 \mathrm{~Hz}$ 2H); 7.45 (t, J = 7.6 Hz, 2H); $7.34(\mathrm{t}, \mathrm{J}=7.4 \mathrm{~Hz}, 1 \mathrm{H}) ; 5.23(\mathrm{~s}, 2 \mathrm{H}) ; 3.49(\mathrm{p}, \mathrm{J}=6.9 \mathrm{~Hz}, 2 \mathrm{H}) ; 1.09(\mathrm{t}, \mathrm{J}=7.1 \mathrm{~Hz}, 3 \mathrm{H})$; ${ }^{13} \mathrm{C}$ NMR spectrum (DMSO-d6): $\delta$ (ppm): 169.40; 165.40;146.27; 130.65; 128.95; 127.92; 125.17; 122.92; 50.64; 38.53; 14.50; HRMS calcd for $\mathrm{C}_{13} \mathrm{H}_{16} \mathrm{~N}_{6} \mathrm{O}_{5}[\mathrm{M}+\mathrm{H}]^{+}$305.1179 Found 305.1177.

$\mathrm{N}$-allyl-2-(2-(4-phenyl-1 H-1,2,3-triazol-1-yl)acetyl)hydrazinecarbothioamide(4c). Yield (80\%), mp $217-219^{\circ} \mathrm{C}$ IR spectrum $\left(\mathrm{v} / \mathrm{cm}^{-1}\right)$ : $3234(\mathrm{NH}) ; 1652(\mathrm{C}=\mathrm{O}) ; 1590 ; 1587 ; 1532 ; 1480 ; 1467(\mathrm{C}=\mathrm{N} / \mathrm{C}=\mathrm{C}) ; 1191(\mathrm{C}=\mathrm{S}) ;{ }^{1} \mathrm{H} \mathrm{NMR}$ spectrum (DMSO-d6): $\delta(\mathrm{ppm}): 10.36(\mathrm{~s}, 1 \mathrm{H}) ; 9.47(\mathrm{~s}, 1 \mathrm{H}) ; 8.53(\mathrm{~s}, 1 \mathrm{H}) ; 8.36(\mathrm{t}, \mathrm{J}=5.6 \mathrm{~Hz}, 1 \mathrm{H}) ; 7.91-7.84(\mathrm{~m}, 2 \mathrm{H})$; 7.45 (t, J = 7.6 Hz, 2H); 7.38-7.29 (m, 1H); 5.84 (ddt, J = 17.3, 10.2, 5.1 Hz, 1H); $5.25(\mathrm{~s}, 2 \mathrm{H}) ; 5.19-5.03(\mathrm{~m}, 2 \mathrm{H}) ; 4.14$ $(\mathrm{t}, \mathrm{J}=5.4 \mathrm{~Hz}, 2 \mathrm{H}) ;{ }^{13} \mathrm{C}$ NMR spectrum (DMSO-d6): $\delta$ (ppm): 165.47; 146.26; 134.80; 130.66; 128.95; 127.92; 125.17; 122.90; 115.32; 50.66; 45.90; HRMS calcd for $\mathrm{C}_{14} \mathrm{H}_{16} \mathrm{~N}_{6} \mathrm{O}_{5}[\mathrm{M}+\mathrm{H}]^{+} 317.1179$ Found 317.1177 .

4-phenyl-5-((4-phenyl-1H-1,2,3-triazol-1-yl)methyl)-4H-1,2,4-triazole-3-thiol(5a). Yield (81\%), mp $220-222{ }^{\circ} \mathrm{C}$; IR spectrum (v/cm $\left.{ }^{-1}\right): 2988(\mathrm{SH}) ; 1590 ; 1527 ; 1482 ; 1460(\mathrm{C}=\mathrm{N} / \mathrm{C}=\mathrm{C}) ;{ }^{1} \mathrm{H}$ NMR spectrum (DMSO-d6): $\delta(\mathrm{ppm}): 8.26$ (s, $1 \mathrm{H}) ; 7.75(\mathrm{~d}, J=7.7 \mathrm{~Hz}, 2 \mathrm{H}) ; 7.51-7.38(\mathrm{~m}, 5 \mathrm{H}) ; 7.37-7.28(\mathrm{~m}, 3 \mathrm{H}) ; 5.26(\mathrm{~s}, 2 \mathrm{H}) ;{ }^{13} \mathrm{C}$ NMR spectrum (DMSO-d6): $\delta$ (ppm): $168.71 ; 146.90 ; 146.34 ; 132.78 ; 130.32 ; 129.64 ; 129.39 ; 128.88 ; 127.98 ; 127.89 ; 125.19 ; 122.07 ; 44.53 ;$ HRMS calcd for $\mathrm{C}_{17} \mathrm{H}_{14} \mathrm{~N}_{6} \mathrm{~S}[\mathrm{M}+\mathrm{H}]^{+} 335.1073$ Found 335.1071.

4-ethyl-5-((4-phenyl-1H-1,2,3-triazol-1-yl)methyl)-4H-1,2,4-triazole-3-thiol (5b). Yield (73\%), mp $224-226{ }^{\circ} \mathrm{C}$; IR spectrum (v/cm $\left.{ }^{-1}\right): 3245(\mathrm{NH}) ; 2962(\mathrm{SH}) ; 1580 ; 1532 ; 1482 ; 1460$ (C=N/C=C); ${ }^{1} \mathrm{H}$ NMR spectrum (DMSO-d6): $\delta$ (ppm): $13.93(\mathrm{~s}, 1 \mathrm{H}) ; 8.70(\mathrm{~s}, 1 \mathrm{H}) ; 7.88(\mathrm{~d}, \mathrm{~J}=7.5 \mathrm{~Hz}, 2 \mathrm{H}) ; 7.44(\mathrm{t}, \mathrm{J}=7.6 \mathrm{~Hz}, 2 \mathrm{H}) ; 7.33(\mathrm{t}, \mathrm{J}=7.4 \mathrm{~Hz}, 1 \mathrm{H}) ; 5.94(\mathrm{~s}$, $2 \mathrm{H}) ; 4.04(\mathrm{q}, \mathrm{J}=7.1 \mathrm{~Hz}, 2 \mathrm{H}) ; 1.02(\mathrm{t}, \mathrm{J}=7.1 \mathrm{~Hz}, 3 \mathrm{H}) ;{ }^{13} \mathrm{C}$ NMR spectrum (DMSO-d6): $\delta(\mathrm{ppm}): 167.23 ; 146.97 ;$ $146.88 ; 130.28 ; 128.94 ; 128.13 ; 125.30 ; 122.18 ; 44.15 ; 38.81 ; 12.89 ; \mathrm{HRMS}$ calcd for $\mathrm{C}_{13} \mathrm{H}_{14} \mathrm{~N}_{6} \mathrm{~S}[\mathrm{M}+\mathrm{H}]^{+} 287.1073$ Found 287.1072.

4-allyl-5-((4-phenyl-1H-1,2,3-triazol-1-yl)methyl)-4H-1,2,4-triazole-3-thiol (5c). Yield (76\%), mp $237-239{ }^{\circ} \mathrm{C}$ IR spectrum $\left(\mathrm{v} / \mathrm{cm}^{-1}\right)$ : $2971(\mathrm{SH}) ; 1591 ; 1530 ; 1482 ; 1457(\mathrm{C}=\mathrm{N} / \mathrm{C}=\mathrm{C}) ;{ }^{1} \mathrm{H}$ NMR spectrum (DMSO-d6): $\delta$ (ppm): 14.00 (s, 1H); $8.65(\mathrm{~s}, 1 \mathrm{H}) ; 7.90-7.82(\mathrm{~m}, 2 \mathrm{H}) ; 7.49-7.40(\mathrm{~m}, 2 \mathrm{H}) ; 7.38-7.28(\mathrm{~m}, 1 \mathrm{H}) ; 5.85(\mathrm{~s}, 2 \mathrm{H}) ; 5.73(\mathrm{ddt}, \mathrm{J}=17.3,10.6$, $5.2 \mathrm{~Hz}, 1 \mathrm{H}) ; 5.03(\mathrm{dq}, \mathrm{J}=10.3,1.4 \mathrm{~Hz}, 1 \mathrm{H}) ; 4.93(\mathrm{dt}, \mathrm{J}=17.1,1.4 \mathrm{~Hz}, 1 \mathrm{H}) ; 4.69(\mathrm{dt}, \mathrm{J}=5.2,1.7 \mathrm{~Hz}, 1 \mathrm{H}) ;{ }^{13} \mathrm{C} \mathrm{NMR}$ spectrum (DMSO-d6): $\delta$ (ppm): 167.76; 147.05; 146.81; 130.65; 130.37; 128.92; 128.06; 125.26; 125.25; 122.29; 117.44; 45.24; 44.15; HRMS calcd for $\mathrm{C}_{14} \mathrm{H}_{14} \mathrm{~N}_{6} \mathrm{~S}[\mathrm{M}+\mathrm{H}]^{+} 299.1073$ Found 299.1072.

5-((4-phenyl-1H-1,2,3-triazol-1-yl)methyl)-1,3,4-oxadiazole-2-thiol(6). Yield (87\%), mp 262-264 ${ }^{\circ} \mathrm{C} ; \quad \mathrm{IR}$ spectrum (v/cm $\left.{ }^{-1}\right): 2961(\mathrm{SH}) ; 1601 ; 1537 ; 1482 ; 1457(\mathrm{C}=\mathrm{N} / \mathrm{C}=\mathrm{C}) ;{ }^{1} \mathrm{H}$ NMR spectrum (DMSO-d6): $\delta$ (ppm): 8.72 (d, J $=1.3 \mathrm{~Hz}, 1 \mathrm{H}) ; 7.92-7.84(\mathrm{~m}, 2 \mathrm{H}) ; 7.48-7.39(\mathrm{~m}, 2 \mathrm{H}) ; 7.33(\mathrm{td}, \mathrm{J}=7.4,1.4 \mathrm{~Hz}, 1 \mathrm{H}) ; 5.98(\mathrm{~d}, \mathrm{~J}=1.6 \mathrm{~Hz}, 2 \mathrm{H}) ;{ }^{13} \mathrm{C} \mathrm{NMR}$ 
spectrum (DMSO-d6): $\delta$ (ppm): 178.19; 158.23; 146.98; 130.23; 129.00; 128.23; 125.38; 122.46; 44.17; HRMS calcd for $\mathrm{C}_{11} \mathrm{H}_{9} \mathrm{~N}_{5} \mathrm{OS}[\mathrm{M}+\mathrm{H}]^{+} 260.0601$ Found 260.0594 .

4-amino-5-((4-phenyl-1H-1,2,3-triazol-1-yl)methyl)-4H-1,2,4-triazole-3-thiol(8). Yield (81\%), mp 271-273 ${ }^{\circ} \mathrm{C}$; IR spectrum (v/cm $\left.{ }^{-1}\right): 3270 ; 3135\left(\mathrm{NH}_{2}\right.$ and $\left.\mathrm{NH}\right) ; 2720(\mathrm{SH}) ; 1615 ; 1560 ; 1485 ; 1461 \quad(\mathrm{C}=\mathrm{N} / \mathrm{C}=\mathrm{C}) ; 1299(\mathrm{C}=\mathrm{S}) ;{ }^{1} \mathrm{H}$ NMR spectrum (DMSO-d6): $\delta$ (ppm): $13.85(\mathrm{~s}, 1 \mathrm{H}) ; 8.73(\mathrm{~d}, J=0.7 \mathrm{~Hz}, 1 \mathrm{H}) ; 8.62(\mathrm{~d}, J=0.7 \mathrm{~Hz}, 1 \mathrm{H}) ; 7.91-7.83(\mathrm{~m}$, $3 \mathrm{H}) ; 7.51-7.40(\mathrm{~m}, 3 \mathrm{H}) ; 7.40-7.29(\mathrm{~m}, 1 \mathrm{H}) ; 5.94(\mathrm{~s}, 1 \mathrm{H}) ; 5.76(\mathrm{~s}, 2 \mathrm{H}) ; 5.68(\mathrm{~s}, 2 \mathrm{H}) ;{ }^{3} \mathrm{C}$ NMR spectrum (DMSO-d6): $\delta$ (ppm): $178.06 ; 167.21 ; 158.22 ; 147.25 ; 146.83 ; 146.58130 .47 ; 130.20 ; 128.89 ; 128.89 ; 128.18 ; 128.00 ; 125.28$; 125.24 ; 122.44; 122.16; 44.04; 43.56; HRMS calcd for $\mathrm{C}_{11} \mathrm{H}_{11} \mathrm{~N}_{7} \mathrm{~S}[\mathrm{M}+\mathrm{H}]^{+} 274.0869$ Found 274.0867 .

(E)-N-benzylidene-2-(4-phenyl-1H-1,2,3-triazol-1-yl)acetohydrazide (9a). Yield (82\%), mp 196-198 ${ }^{\circ} \mathrm{C}$; IR spectrum $\left(\mathrm{v} / \mathrm{cm}^{-1}\right): 3185(\mathrm{NH}) ; 1673(\mathrm{C}=\mathrm{O}) ; 1608 ; 1583 ; 1483 ; 1458(\mathrm{C}=\mathrm{N} / \mathrm{C}=\mathrm{C}) ;{ }^{1} \mathrm{H}$ NMR spectrum (DMSO-d6): $\delta$ (ppm): $11.90(\mathrm{~s}, 1 \mathrm{H}) ; 8.56(\mathrm{~s}, 1 \mathrm{H}) ; 8.08(\mathrm{~s}, 1 \mathrm{H}) ; 7.92-7.83(\mathrm{~m}, 2 \mathrm{H}) ; 7.80-7.73(\mathrm{~m}, 2 \mathrm{H}) ; 7.51-7.41(\mathrm{~m}, 5 \mathrm{H}) ; 7.39-7.30$ $(\mathrm{m}, 1 \mathrm{H}) ; 5.76(\mathrm{~s}, 2 \mathrm{H}) ;{ }^{13} \mathrm{C}$ NMR spectrum (DMSO-d6): $\delta(\mathrm{ppm}): 167.38 ; 146.14 ; 144.57 ; 133.84 ; 130.80 ; 130.16$; $128.95 ; 128.84 ; 127.83 ; 127.24 ; 127.07 ; 125.16 ; 125.12 ; 123.21 ; 50.71 ; \mathrm{HRMS}$ calcd for $\mathrm{C}_{17} \mathrm{H}_{15} \mathrm{~N}_{5} \mathrm{O}[\mathrm{M}+\mathrm{H}]^{+} 306.1349$ Found 306.1348 .

(E)-N-(4-chlorobenzylidene)-2-(4-phenyl-1 H-1,2,3-triazol-1-yl) acetohydrazide (9b). Yield (85\%), mp 198-199 ${ }^{\circ} \mathrm{C}$; IR spectrum $\left(\mathrm{v} / \mathrm{cm}^{-1}\right): 3160(\mathrm{NH}) ; 1668(\mathrm{C}=\mathrm{O}) ; 1610 ; 1578 ; 1488 ; 1461(\mathrm{C}=\mathrm{N} / \mathrm{C}=\mathrm{C}) ;{ }^{1} \mathrm{H}$ NMR spectrum (DMSOd6): $\delta$ (ppm): $11.96(\mathrm{~s}, 1 \mathrm{H}) ; 8.56(\mathrm{~s}, 1 \mathrm{H}) ; 8.06(\mathrm{~s}, 1 \mathrm{H}) ; 7.87(\mathrm{~d}, \mathrm{~J}=7.5 \mathrm{~Hz}, 2 \mathrm{H}) ; 7.83-7.73(\mathrm{~m}, 2 \mathrm{H}) ; 7.56-7.42(\mathrm{~m}, 4 \mathrm{H})$; 7.39-7.30 (m, 1H); $5.76(\mathrm{~s}, 2 \mathrm{H}) ;{ }^{3} \mathrm{C}$ NMR spectrum (DMSO-d6): $\delta(\mathrm{ppm}): 167.47 ; 162.21 ; 146.67 ; 146.27 ; 146.15 ;$ 143.27; 134.79; 134.59; 132.86; 130.79; 130.67; 128.94; 128.90; 128.88; 128.73; 127.89; 127.82; 125.16; 125.11; 123.18; $122.89 ; 51.15 ; 50.70$; HRMS calcd for $\mathrm{C}_{17} \mathrm{H}_{14} \mathrm{CIN}_{5} \mathrm{O}[\mathrm{M}+\mathrm{H}]^{+} 340.0960$ Found 340.0962 .

(E)-N-(4-bromobenzylidene)-2-(4-phenyl-1 H-1,2,3-triazol-1-yl)acetohydrazide (9c). Yield (87\%), mp 201-203 ${ }^{\circ} \mathrm{C}$; IR spectrum $\left(\mathrm{v} / \mathrm{cm}^{-1}\right): 3165(\mathrm{NH}) ; 1680(\mathrm{C}=\mathrm{O}) ; 1609 ; 1580 ; 1483 ; 1461(\mathrm{C}=\mathrm{N} / \mathrm{C}=\mathrm{C}) ;{ }^{\mathrm{H}} \mathrm{NMR}$ spectrum (DMSOd6): $\delta(\mathrm{ppm}): 11.96(\mathrm{~s}, 1 \mathrm{H}) ; 8.55(\mathrm{~s}, 1 \mathrm{H}) ; 8.05(\mathrm{~s}, 1 \mathrm{H}) ; 7.91-7.83(\mathrm{~m}, 2 \mathrm{H}) ; 7.76-7.69(\mathrm{~m}, 2 \mathrm{H}) ; 7.69-7.61(\mathrm{~m}, 3 \mathrm{H}) ; 7.51-$ $7.42(\mathrm{~m}, 2 \mathrm{H}) ; 7.39-7.30(\mathrm{~m}, 1 \mathrm{H}) ; 5.76(\mathrm{~s}, 2 \mathrm{H}) ;{ }^{13} \mathrm{C}$ NMR spectrum (DMSO-d6): $\delta$ (ppm): 167.48; 146.15; 143.18; $133.14 ; 131.86 ; 131.82 ; 130.78 ; 129.10 ; 128.96 ; 128.94 ; 127.83 ; 125.16 ; 125.11 ; 123.40 ; 123.18 ; 50.70 ;$ HRMS calcd for $\mathrm{C}_{17} \mathrm{H}_{14} \mathrm{BrN}_{5} \mathrm{O}[\mathrm{M}+\mathrm{H}]^{+} 384.0454$ Found 384.0455 .

(E)-N-(4-fluorobenzylidene)-2-(4-phenyl-1H-1,2,3-triazol-1-yl)acetohydrazide (9d). Yield (84\%), mp 199-200 ${ }^{\circ} \mathrm{C}$; IR spectrum $\left(\mathrm{v} / \mathrm{cm}^{-1}\right): 3175(\mathrm{NH}) ; 1677(\mathrm{C}=\mathrm{O}) ; 1606 ; 1581 ; 1486 ; 1462(\mathrm{C}=\mathrm{N} / \mathrm{C}=\mathrm{C}) ;{ }^{1} \mathrm{H}$ NMR spectrum (DMSOd6): $\delta(\mathrm{ppm}): 11.90(\mathrm{~s}, 1 \mathrm{H}) ; 8.56(\mathrm{~d}, \mathrm{~J}=2.5 \mathrm{~Hz}, 1 \mathrm{H}) ; 8.07(\mathrm{~d}, \mathrm{~J}=2.5 \mathrm{~Hz}, 1 \mathrm{H}) ; 7.92-7.75(\mathrm{~m}, 5 \mathrm{H}) ; 7.46(\mathrm{td}, \mathrm{J}=7.7,2.6$ $\mathrm{Hz}, 3 \mathrm{H}) ; 7.39-7.25(\mathrm{~m}, 1 \mathrm{H}) ; 5.75(\mathrm{~d}, \mathrm{~J}=2.2 \mathrm{~Hz}, 1 \mathrm{H}) ; 5.30(\mathrm{~d}, \mathrm{~J}=2.0 \mathrm{~Hz}, 1 \mathrm{H}) ;{ }^{13} \mathrm{C}$ NMR spectrum (DMSO-d6): $\delta$ (ppm): 167.39; 146.13; 143.40; 130.79; 130.50; 129.33; 129.25; 128.94; 127.82; 125.15; 125.10; 123.18; 116.00; 115.78; 50.70; HRMS calcd for $\mathrm{C}_{17} \mathrm{H}_{14} \mathrm{FN}_{5} \mathrm{O}[\mathrm{M}+\mathrm{H}]^{+} 324.1255$ Found 324.1252.

(E)-N-(4-(dimethylamino)benzylidene)-2-(4-phenyl-1H-1,2,3-triazol-1-yl)aceto- hydrazide (9e). Yield (78\%), $\mathrm{mp} 192-194{ }^{\circ} \mathrm{C}$; IR spectrum $\left(\mathrm{v} / \mathrm{cm}^{-1}\right)$ : $3255(\mathrm{NH}) ; 1677(\mathrm{C}=\mathrm{O}) ; 1613 ; 1576 ; 1487 ; 1461 \quad(\mathrm{C}=\mathrm{N} / \mathrm{C}=\mathrm{C}) ;{ }^{1} \mathrm{H} \mathrm{NMR}$ spectrum (DMSO-d6): $\delta$ (ppm): $11.58(\mathrm{~d}, \mathrm{~J}=2.9 \mathrm{~Hz}, 1 \mathrm{H}) ; 8.58-8.52(\mathrm{~m}, 1 \mathrm{H}) ; 7.96-7.82(\mathrm{~m}, 3 \mathrm{H}) ; 7.60-7.41(\mathrm{~m}, 4 \mathrm{H})$; 7.35 (ddd, J = 8.9, 5.3, 3.2 Hz, $1 \mathrm{H}) ; 6.74(\mathrm{dt}, \mathrm{J}=9.0,2.0 \mathrm{~Hz}, 2 \mathrm{H}) ; 5.69(\mathrm{~d}, \mathrm{~J}=3.2 \mathrm{~Hz}, 2 \mathrm{H}) ; 3.07-2.84(\mathrm{~m}, 6 \mathrm{H}) ;{ }^{13} \mathrm{C}$ NMR spectrum (DMSO-d6): $\delta$ (ppm): 166.66; 151.52; 146.09; 145.37; 130.83; 128.93; 128.60; 128.35; 127.79; $125.14 ; 125.10 ; 123.21 ; 121.13 ; 111.76 ; 50.65 ; 39.77 ; 30.70 ;$ HRMS calcd for $\mathrm{C}_{19} \mathrm{H}_{20} \mathrm{~N}_{6} \mathrm{O}[\mathrm{M}+\mathrm{H}]^{+} 349.1771$ Found 349.1765 .

(E)-2-(4-phenyl-1H-1,2,3-triazol-1-yl)- $\mathrm{N}$-(1-phenylethylidene)acetohydrazide(9f). Yield (84\%), mp 196-198 ${ }^{\circ} \mathrm{C}$ IR spectrum $\left(\mathrm{v} / \mathrm{cm}^{-1}\right): 3165(\mathrm{NH}) ; 1673(\mathrm{C}=\mathrm{O}) ; 1610 ; 1576 ; 1487 ; 1461(\mathrm{C}=\mathrm{N} / \mathrm{C}=\mathrm{C}) ;{ }^{1} \mathrm{H}$ NMR spectrum (DMSO-d6): $\delta$ (ppm): $11.12(\mathrm{~s}, 1 \mathrm{H}) ; 8.57(\mathrm{~s}, 1 \mathrm{H}) ; 7.94-7.84(\mathrm{~m}, 5 \mathrm{H}) ; 7.50-7.40(\mathrm{~m}, 4 \mathrm{H}) ; 7.37-7.32(\mathrm{~m}, 1 \mathrm{H}) ; 5.80(\mathrm{~s}, 2 \mathrm{H}) ; 2.31(\mathrm{~s}, 3 \mathrm{H}) ;$ ${ }^{13} \mathrm{C}$ NMR spectrum (DMSO-d6): $\delta$ (ppm): $168.31 ; 149.28 ; 146.16 ; 137.83 ; 130.85 ; 129.33 ; 128.94 ; 128.41 ; 127.81$; 126.29; 125.13; 123.20; 51.23; 13.80; HRMS calcd for $\mathrm{C}_{18} \mathrm{H}_{17} \mathrm{~N}_{5} \mathrm{O}[\mathrm{M}+\mathrm{H}]^{+} 320.1506$ Found 320.1503 .

\subsection{Biology}

\subsubsection{Antibacterial screening Organisms and culture conditions}

The used bacterial cultures were obtained from Assiut University Mycological Center (AUMC), Assiut University. The synthesized compounds (2, 3, 4a-c, 5a-c, 6, 8, and 9a-f) were tested for their in-vitro antibacterial activity in comparison to ciprofloxacin as a reference drug using the standard agar cup diffusion method[19] against Staphylococcus aureus(AUMC B54) as a representative of Gram positive strains, while the Gram negative strains were represented by Escherichia coli (AUMC B69).

\section{Materials and method}

Bacterial strains were individually cultured for $48 \mathrm{~h}$ in $100 \mathrm{~mL}$ conical flasks containing $30 \mathrm{~mL}$ Nutrient Agar (NA). Assay was done in $10 \mathrm{~cm}$ sterile Petri dishes in which one $\mathrm{mL}$ bacterial suspension and $15 \mathrm{~mL}$ of NA were poured. Plates were shaken gently to homogenize the inocula. After solidification of the media, $5 \mathrm{~mm}$ cavities were cut in the solidified agar (4 cavities/plate) using sterile cork borer. The test compounds (2, 3, 4a-c, 5a-c, 6, 8, and 9a-f) and ciprofloxacin were dissolved in dimethyl sulfoxide $(100 \mu \mathrm{mol} / \mathrm{mL})$ and were pipeted in the cavities. In addition, other cavities were pipeted with the solvent (DMSO) and served as a negative control. The seeded plates were incubated at $28 \pm 2^{\circ} \mathrm{C}$ for $48 \mathrm{~h}$.

The radii of inhibition zones (in $\mathrm{mm}$ ) of triplicate sets were measured and the results are cited in table II. 


\subsubsection{Antifungal screening Organisms and culture conditions}

The used Sabouraud Agar (SA) media were prepared in Assiut University Mycological Center (AUMC), Assiut University. The test compounds $(\mathbf{2}, \mathbf{3}, \mathbf{4 a - c}, \mathbf{5 a - c , 6}, \mathbf{8}$, and $\mathbf{9 a - f})$ were evaluated for their antifungal activity in-vitro, in comparison to fluconazole as a reference drug using the standard agar cup diffusion method[20] against a pathogenic fungal species Candida albicans (Robin) Berkhout (AUMC 418).

\section{Materials and method}

Spore suspension in sterile distilled water was prepared from 7 days old culture of the test fungi growing on Sabouraud's dextrose broth $(30 \mathrm{~mL})$ media in $100 \mathrm{~mL}$ conical flasks. The final spore concentration was nearly $5 \times 104 \mathrm{spores} / \mathrm{mL}$. About $15 \mathrm{~mL}$ of the growth medium was introduced on sterilized Petri dishes of $10 \mathrm{~cm}$ diameter and inoculated with $1 \mathrm{~mL}$ of spore suspension. Plates were shaken gently to homogenize the inocula. After solidification of the media, $5 \mathrm{~mm}$ cavities were cut in the solidified agar (4 cavities/plate) using sterile cork borer and was filled with the solutions of the test compounds (2, 3, 4a-c, 5a-c, 6, 8, and 9a-f) and fluconazole (100 $\mu \mathrm{mol} / \mathrm{mL}$ in DMSO). In addition, other cavities were impregnated with the solvent (DMSO) and served as a negative control. The seeded plates were incubated at $28 \pm 2^{\circ} \mathrm{C}$ for 7 days. The radii of inhibition zones (in $\mathrm{mm}$ ) of triplicate sets were measured at successive intervals during the incubation period and the results are displayed in table II.

\section{REFERENCES}

1- W.Q. Fan, A.R. Katritzky, 1,2,3 Triazoles. In Comprehensive Heterocycle Chemistry II, A.R. Katritzky, C.W. Rees, E.F.V.Scriven, Eds., Pergamon Press: New York, NY, USA, Vol. 4. 1996; pp.1-126.

2- A.R. Katritzky, Y. Zhang, S.K. Singh, Heterocycles 60(2003)1225-1239.

3- R. Alvarez, S. Velazquez, R. San, S. Aquaro, C.E. De, C.F. Perno, A. Karlsson, J. Balzarini, M.J. Camarasa, J. Med. Chem. 37 (1994) 4185-4194.

4- S. Velazques, R. Alvarez, C. Perez, F. Gago, C.E. De, J.Balzarini, J.M. Camarasa, Antiviral Chem. Chemother. 9 (1998) 481-489.

5- M. Whiting, J. Muldoon, Y.C. Lin, S.M. Silverman, W. Lindstrom, A.J. Olson, H.C. Kolb, M.G. Finn, B.K. Sharpless, J.H. Elder, V.V. Fokin, Angew. Chem. Int. Ed. 45 (2006) 1435-1439.

6- A. Brik, J. Muldoon, Y.C. Lin, J.C. Elder, D.S. Goodsell, A.J. Olson, V.V. Fokin, B.K. Sharpless, C.H. Wong, Chem. Bio. Chem. 4 (2003) 1246-1248.

7- M. J. Genin, D. A. Allwine, D. J. Anderson, M. R. Barbachyn, D. M. Emmert, S. A. Garmon, B. H. Yagi, J. Med. Chem. 43 (2000) 953-970.

8- L. L. Brochunier, E. R. Parmee, H. O. Ok, M. R. Candelore, M. A. Cascieri, L. F. Colwell, A. E. Weber, Bioorg. Med. Chem. Lett. 10 (2000) 2111-2114.

9- V. Pande, M. J. Ramos, Bioorg. Med. Chem. Lett. 15 (2005) 5129-5135.

10- P. H. Olesen, A. R. Sorensen, B. Ursö, P.Kurtzhals, A. N. Bowler, U.Ehrbar, B. F. Hansen, J. Med. Chem. 46 (2003) 3333-3341.

11- A. Karsinski, Z.Radic, R.Manetsch, J. Raushel, P. Taylor, B. K. Sharpless, H. C. Kolb, J. Am. Chem. Soc. 127 (2005) 6686-6692.

12- V. P. Mocharla, B. Colasson, L. V. Lee, S. Roeper, B. K. Sharpless, C. H. Wong, Angew. Chem. Int. Ed.44(2005) 116-120.

13- R. G. Micetich, S. N.Maiti, P. Spevak, T. W. Hall, S.Yamabe, N. Ishida, M. Tanaka, T. Yamazaki, A. Nakai, K. Ogwawa, J. Med. Chem.30 (1987) 1469-1474.

14- P. Actor, J. V. Uri, L. Phillips, C. S. Sachs, J. R. G.Zajac, D. A.Berges, G. L. Dunn, J. R. E. Hoover, J. A.Weisbach, J. Antibiot.28(1975) 594-601.

15- R. A. Devasia, T. F. Jones, J. Ward, L. Stafford, H. Hardin, C. Bopp, M. Beatty, E. Mintz, W. Schaffner, Am. J. Med.10(2006) 119-168.

16- F. Qadri, A. M. Svennerholm, A. S. G. Faruque, R. B. Sack, Clin. Microbiol. Rev.18(2005) 465-483.

17- C. M. Nolan, E. G. Chalhub,T. Yamauchi, Antimicrob. Agents Chemother.16(1979) 171-175.

18- L. R. Heraclio, C. P. Emilio, R. L. Susana, P. Imelda, V. R. Brianda, S. Rosa, C. Oscar, ARKIVOC 3 (2013) $139-164$.

19- A. M. Clark, F. S. El-Feraly, W. S. Li, J. Pharm. Sci.70 (1981) 951-952.

20- A. Felten, B. Grandly, P. H. Lagrange, I.Casin, J. Clin. Microbiol.40 (2002) 2766-2771. 